\title{
ADPF 442: A TUTELA PENAL DA VIDA NAS AUDIÊNCIAS PÚBLICAS SOBRE A DESCRIMINALIZAÇÃO DO ABORTO
}

\section{ADPF 442: PENAL PROTECTION OF LIFE IN PUBLIC HEARINGS ABOUT DECRIMINALIZATION OF ABORTION}

Recebimento: 8 jun. 2020

Aceitação: 6 abr. 2021

Bianca Petri da Silva

Graduada em Direito

Afiliação institucional: Universidade Federal de Santa Maria - UFSM - (Santa Maria, RS, Brasil)

Lattes iD: http://lattes.cnpq.br/8063841237362111

Email: biancapetri95@gmail.com

Francielle Benini Agne Tybusch

Doutora em Direito

Afiliação institucional: Universidade Franciscana - UFN - (Santa Maria, RS, Brasil)

Lattes iD: http://lattes.cnpq.br/4400702817251869

Email: francielleagne@gmail.com

Marília de Nardin Budó

Doutora em Direito

Afiliação institucional: Universidade Federal de Santa Catarina - UFSC - (Florianópolis, SC, Brasil)

Lattes iD: http://lattes.cnpq.br/6586203658704833

Email: mariliadb@yahoo.com.br

Como citar este artigo / How to cite this article (informe a data atual de acesso / inform the current date of access):

SILVA, Bianca Petri da; TYBUSCH, Francielle Benini Agne; BUDÓ, Marília de Nardin. ADPF 442: a tutela penal da vida nas audiências públicas sobre a descriminalização do aborto. Revista da Faculdade de Direito UFPR, Curitiba, v. 66, n. 2, p. 127-154, maio/ago. 2021. ISSN 2236-7284. Disponível em: https://revistas.ufpr.br/direito/article/view/74412. Acesso em: 31 ago. 2021. DOI: http://dx.doi.org/10.5380/rfdufpr.v66i2.74412.

\section{RESUMO}

Neste artigo são analisados discursos proferidos nas audiências públicas realizadas no âmbito da Ação de Descumprimento de Preceito Fundamental n 442, a respeito dos sentidos atribuídos à intervenção penal do Estado em relação à prática de aborto. A pesquisa foi estruturada por meio da metodologia da Teoria Fundamentada nos Dados. O marco teórico do trabalho é a criminologia crítica e feminista, bem como os estudos de gênero. Os resultados apontam para uma estrutura argumentativa prócriminalização do aborto que parte da linguagem dos direitos, tratando da questão da origem da vida, para pensar a tutela penal do embrião. A mulher é construída como objeto e meio, enquanto o feto se torna sujeito e fim. A ruptura com a redução da mulher ao seu suposto destino biológico provém de grupos anticriminalização que, ao compreender a criminalização do aborto - que para eles obedece a 
uma lógica de controle e morte - como um desrespeito ao direito à vida das mulheres, apresentam uma compreensão feminista e interseccional.

\title{
PALAVRAS-CHAVE
}

ADPF 442. Criminalização do aborto. Criminologia feminista.

\begin{abstract}
This article analyzes speeches given at public hearings carried out in the context of Action for Noncompliance with Fundamental Precept (ADPF, in its Portuguese initials) $n^{\circ} 442$, regarding the meanings attributed to the State's punitive intervention regarding abortion. The research was structured using the Grounded Theory methodology. The theoretical framework is critical and feminist criminology, as well as gender studies. The results point to an argumentative structure procriminalization of abortion that starts from the language of rights, dealing with the question of the origin of life, to think about the criminal protection of the embryo. The woman is constructed as an object and means, while the fetus becomes a subject and an end. The rupture with the reduction of women to their supposed biological destiny comes from anti-criminalization groups that, by understanding the criminalization of abortion - which to them obeys a logic of control and death - as a disrespect for the right to life of women, present a feminist and intersectional understanding.
\end{abstract}

\section{KEYWORDS}

ADPF 442. Abortion criminalization. Feminist criminology.

\section{INTRODUÇÃO}

A descriminalização do aborto é uma das pautas centrais de reivindicação dos movimentos feministas. No Brasil, desde meados dos anos 1970, essa pauta se intensificou, gerando fortes reações contrárias de setores conservadores, em especial da ala religiosa. Porém, foi somente com o fim da ditadura civil-militar e a formação da Assembleia Nacional Constituinte (1987-1988) que o conflito institucional entre as agendas favorável e contrária à descriminalização e legalização do aborto tornou-se significativo (MACHADO; MACIEL, 2017). Enquanto para as feministas esse direito representa a garantia da autonomia e liberdade das mulheres, em uma sociedade patriarcal, e simultaneamente uma questão a ser pensada a partir de políticas públicas de garantia da saúde sexual e reprodutiva das mulheres, para os movimentos conservadores o feto deve ser reconhecido como sujeito de direitos, defendendo-se a tutela penal da vida desde a concepção. No contexto parlamentar mais recente no País, esses mesmos setores conservadores têm se valido de argumentos supostamente científicos nos campos da medicina e da biologia para, mediante discurso jurídico, propor alterações 
legislativas criminalizando o aborto em todos os casos (BIROLI, 2018; BUDÓ; RODRIGUES; GINDRI, 2020).

Especialmente desde 2014, as legislaturas federais têm sido consideradas as mais conservadoras desde o fim da ditadura civil-militar no Brasil (QUEIROZ, 2018), inclusive mobilizando elementos identitários conservadores na sua atuação legislativa. O Supremo Tribunal Federal (STF) tem exercido um papel contramajoritário nesse contexto, a exemplo da autorização do aborto em caso de anencefalia do feto, na Ação de Descumprimento de Preceito Fundamental (ADPF) $\mathrm{n}^{\circ}$ 54, em 2012 (BRASIL, 2012). Em 2016, ainda, a segunda turma do STF concedeu uma ordem de habeas corpus para duas pessoas acusadas de praticarem aborto, as quais manteriam uma clínica clandestina. Na decisão, o relator considerou que a criminalização do aborto seria incompatível com vários direitos fundamentais da mulher (BRASIL, 2016a).

Partindo desse precedente, em março de 2017, o Partido Socialismo e Liberdade (PSOL) propôs a $\mathrm{ADPF} \mathrm{n}^{\circ}$ 442, pedindo à Corte a declaração de não recepção dos artigos 124 e 126 do Código Penal pela Constituição Federal. Os artigos definem como crime a interrupção da gravidez tanto para a mulher, quanto para quem a ajuda a abortar. A ADPF 442 ainda não foi julgada, porém, já foram realizadas duas audiências públicas para debater o tema.

Nesse cenário, o presente artigo parte do marco teórico da criminologia crítica feminista de modo a investigar o papel do sistema penal no controle das mulheres mediante estereótipos de gênero socialmente construídos. Para se alcançar tal compreensão, o trabalho tem como ponto de partida alguns pressupostos decorrentes da adoção de tal marco teórico: a deslegitimação teórica e prática do direito penal para cumprir as funções de garantia dos direitos do indivíduo, de tutela de bens jurídicos e de prevenção da criminalidade e o deslocamento do objeto da criminologia às instâncias que fabricam e controlam a delinquência (ANDRADE, 2012). A noção de deslegitimação decorre da verificação de que os processos de criminalização estruturalmente recrutam as pessoas mais vulneráveis ao sistema penal (BARATTA, 2011). As funções declaradas da pena, baseadas no caráter excepcional da conduta criminosa e na anormalidade de quem a perpetra, propondo a ressocialização da pessoa criminalizada e a prevenção da criminalidade, aparentemente fracassaram. Na realidade, verifica-se o cumprimento de funções não declaradas (reais) de repressão e controle seletivo das camadas sociais economicamente inferiores, de corpos negros, em uma perseguição racista operada pelo Estado, e de corpos desviados de suas funções, sejam mulheres malcomportadas no seu papel social, sejam pessoas que exercem sua sexualidade e expressam sua identidade de gênero em desconformidade com o sexo socialmente construído e com o binarismo (CAMPOS, 2017). Assim, o sistema penal tem operado como forma de gestão diferencial das ilegalidades (FOUCAULT, 1987), 
tanto no sentido negativo do extermínio dos indesejáveis (FLAUZINA, 2008), quanto no sentido positivo de conformação desses corpos aos estereótipos que os subalternizam.

Com fundamento nesses marcos teóricos, esta pesquisa parte do seguinte questionamento: como a intervenção penal do Estado, no debate sobre a descriminalização do aborto, é representada nos discursos proferidos nas audiências públicas da ADPF 442? Para a execução da pesquisa, utilizase a metodologia da Teoria Fundamentada nos Dados (TFD), compreendida como um método “prevalentemente indutivo”. Isso porque, segundo Ricardo Cappi (2017), a TFD não pode ser conceituada como um método de abordagem exclusivamente indutivo, já que a observação sempre depende de "uma pré-leitura teórica da realidade, por parte do observador-pesquisador, que jamais poderia ser concebido como neutro" (CAPPI, 2017, p. 387). O trabalho parte da elaboração de algumas hipóteses induzidas da análise dos discursos proferidos, acerca da intervenção penal do Estado na prática do aborto, nas audiências públicas, para, então, construir hipóteses mais abstratas sobre o objeto de estudo.

\section{MATERNIDADE COMPULSÓRIA E ESTERILIZAÇÕES INVOLUNTÁRIAS: REALIDADES DO CONTROLE DOS CORPOS DAS MULHERES SOB AS LENTES DA CRIMINOLOGIA FEMINISTA}

O ano é 2020, e o cenário é um hospital. Por trás de seus muros, está uma criança de dez anos, grávida. A gravidez resulta de estupros, que, relata a menina, sofre desde os seis anos. A gravidez resultante de estupro é uma das situações nas quais o Código Penal brasileiro garante - em abstrato - a possibilidade de sua interrupção legal. Porém, o hospital em questão está a quase 2.000 quilômetros do local onde essa menina, cujo direito é o de abortar, reside, pois lá nenhum hospital aceitou cumprir a lei. Do lado de fora do hospital para onde a menina foi levada, correntes de oração se formam, e, aos brados, pessoas gritam: “assassinos!”. Mesmo com a pressão exercida posteriormente identificada com a participação da ministra da Mulher, da Família e dos direitos humanos (VILA-NOVA, 2020), a interrupção da gravidez ocorreu, e a vontade da menina e de sua avó foi levada em consideração. Dias depois, o Ministério da Saúde editou uma nova normativa a respeito da interrupção legal da gravidez, criando óbices à realização do procedimento (BRASIL, 2020, p. 359). Assim, por meio de atos administrativos, o Executivo brasileiro tem adotado como prática aumentar o constrangimento das mulheres que, por direito, podem abortar.

Esse cenário é ilustrativo do momento vivido hoje no Brasil: ao invés de o foco do Executivo se direcionar ao estupro de crianças e à falta de uma rede de proteção daquela e de tantas outras meninas, a violência sexual ficou absolutamente de fora do debate. Os holofotes se dirigiram para o 
aborto, a ponto de se construírem processos informais de criminalização, não somente do médico, mas da criança e de sua avó. A pergunta que fica então é: o que há de tão ameaçador na prática do aborto legal, a ponto de, mesmo em um caso limite, a polêmica ter tomado conta?

A resposta para essa pergunta tem sido construída na teoria feminista, na qual também a criminologia feminista se inspira para desconstruir duas figuras culturalmente acionadas cada vez que um caso como este está em cena: a do homem patologizado que estupra; a da mulher vítima que também é culpada pelo próprio estupro (ANDRADE, 2005). A inversão dos papéis permite que o homem seja construído como uma vítima da sedução da mulher, que não se contém a exercer seu papel de recato. Simultaneamente, a menina ou mulher é culpabilizada (PITCH, 2009, p. 121). Tal dupla é construída a partir de estereótipos de gênero, porém, em uma sociedade na qual o racismo estrutura as relações sociais, não se pode desconsiderar a sua intersecção com a raça (CRENSHAW, 1989). À mulher negra, o racismo atribui signos, por um lado, de sexualização, que historicamente têm justificado todo o tipo de violência; por outro lado, signos que a afastam do próprio estereótipo de uma mulher na sociedade burguesa patriarcal, vinculada à fragilidade, passividade, resignação, etc. Contudo, quando nesta dupla o homem negro é identificado como o estuprador, e a vítima é uma mulher branca, então a culpabilização desta pode não predominar, tendo em vista os signos atribuídos ao próprio homem negro, de desumanização e sexualização (ANDRADE, 2018; CRENSHAW, 1989; GONZALEZ, 2020).

O caso da menina de 10 anos quase impedida de abortar legalmente após anos de estupro é interessante porque desnuda os estereótipos de gênero: violência sexual e aborto se relacionam na compreensão sobre qual é o papel da mulher na sociedade. Já não é de hoje que a teoria e a práxis feministas têm apontado a forma como o corpo de mulher - um corpo com raça, etnia, gênero e sexualidade - é atravessado por relações de poder (BIROLI, 2018; BODELÓN, 2009). Desde a compreensão sobre o que é o estupro, até o sentido do que é o aborto, o exercício do poder redunda na subjugação e controle desse outro.

Esse controle do “outro” ocorre historicamente a partir do essencialismo biológico, procurando justificar a inferioridade não apenas das mulheres pelo gênero, mas também de outros “outros”, pela raça. Com o colonialismo, os europeus se consolidaram no centro do poder hegemônico, decorrente, em grande parte, do acúmulo material proveniente das colônias, de modo que passaram a ser consideradas válidas apenas as perspectivas europeias acerca da humanidade. Essa hegemonia, segundo Aníbal Quijano (2005), permitiu que os europeus se autoproclamassem como povo superior aos demais, os quais seriam 'o outro colonizado’: o índio, o negro, o mestiço, ou seja, os inferiores e de cujo saber se prescinde. 
Em razão da urgência de se justificar certos interesses hegemônicos e econômicos, o discurso científico foi - e ainda é - utilizado para confirmar a pretensa supremacia intelectual, racial e biológica de quem hoje, pelos privilégios estruturalmente construídos, revela-se como classe dominante. Diversas “verdades” sobre gênero e sexualidade foram “reveladas” pela ciência, que ao se socorrer de sua suposta imparcialidade, subordina o conhecimento aos padrões morais, sempre “pronta a correr ao socorro da lei e da opinião dominante” (FOUCAULT, 1999, p. 54).

De acordo com Sandra Harding (1993, p. 13-14), uma das implicações da posição vantajosa do homem branco europeu foi a exclusão das mulheres enquanto produtoras de conhecimento e ciência, além de não serem foco central de estudos científicos. O ser científico, então, estava intimamente ligado à figura do homem imparcial, em detrimento da figura feminina emocional e irracional. Dessa forma, o mundo só poderia ser conhecido por meio da racionalidade europeia ocidental, que contrapunha, em categorias binárias, o homem branco europeu frente àquilo que é feminino ou colonizado.

Tal perspectiva, porém, está aliada a formas de conhecer o mundo que certamente não levaram em conta o ponto de vista desses outros. É o que a epistemologia feminista tem demonstrado, ao estudar "a maneira como o sistema sexo-gênero influencia e deveria influenciar em nossas concepções do conhecimento e nos métodos de investigação e justificação” (NICOLÁS, 2009, p. 26, tradução nossa). Isso implica que o determinismo biológico, que baseia essa diferenciação sexual natural entre homens e mulheres nesta sociedade, é produto de uma ciência e de lugares legitimados de produção de conhecimento que têm deixado de fora mais da metade da população.

Heleieth I. B. Saffioti (1987, p. 8-9) refere que a hegemonia masculina se legitimou por meio do ideário do que é ser mulher, concebendo que, ao nascer com determinado sexo, uma pessoa possui diversas características inerentes a ela. A construção social da maternidade nas sociedades burguesas faz com que a subjetividade da mulher seja completamente apagada do debate político. De acordo com Poovey (1992, p. 243, tradução nossa), “a própria existência de uma natureza feminina é um pressuposto desse argumento, persistindo a ideia de que um instinto maternal e o desejo de ser mãe são intrínsecos na essência de ser uma mulher”. Segundo Donath (2017, p. 27), o potencial reprodutivo da anatomia feminina tem promovido uma obrigatoriedade biológica de que as mulheres sejam mães: “[...] os conceitos históricos e culturais aprisionam as mulheres em uma 'ausência de escolha ilusória’ por causa de seu sexo biológico, uma vez que a sociedade usa a 'linguagem da natureza’ para persuadi-las a conceber e dar à luz, muitas vezes impondo uma verdadeira tirania biológica”. 
Ocorre que a atribuição de condutas específicas às mulheres não decorre do seu sexo biológico, mas da construção social do gênero mulher (SCOTT, 1995, p. 75). Portanto, a igualdade de gênero deve ter como norte a desconstrução dessa conexão ideológica que se faz entre o sexo biológico e os papéis sociais de cada gênero, pois só assim se romperá com o modelo androcêntrico de ciência e com o poder masculino, os quais, mediante um círculo vicioso, perpetuam, “ao mesmo tempo, as condições e consequências das desigualdades sociais dos gêneros” (BARATTA, 1999, p. 21).

Nessa esfera se desenrola o debate sobre os direitos sexuais e reprodutivos das mulheres, sistematicamente negados, e presentes na crítica feminista ao patriarcado. A liberdade sexual, o direito ao próprio corpo e a autonomia se constroem nessas mesmas relações de poder, de modo que, ao reivindicarem o direito a escolherem se querem ou não ser mães, e se devem ou não praticar o aborto, os movimentos de mulheres estremecem as estruturas desse sistema.

A criminalização do aborto serve, em primeiro lugar, para representar simbolicamente o papel conferido à mulher na esfera (privada) da reprodução natural. Depois, para assegurar o domínio patriarcal sobre a mulher, por derradeiro, para impor à mesma - através de sua função na esfera reprodutiva - um papel subordinado no regime da transmissão da propriedade e na formação dos patrimônios (BARATTA, 1999, p. 49).

Ao tornar o abortamento uma prática lícita, “a mulher não estaria mais ligada à noção de uma natureza teleológica imanente, que lhe impõe a maternidade e suas funções reprodutivas” (COSTA, 2018, p. 35), podendo exercer sua autonomia corporal de forma livre e política. Ao negar a possibilidade do aborto às mulheres, elas tornam-se meio para um fim com o qual não necessariamente concordam, o que não se revela ético ou moralmente tolerável (KREUZ, 2016, p. 61). Ao criminalizar o aborto, reforça-se a discriminação contra as mulheres, especialmente aquelas que já estão em situação de subalternidade - mulheres negras e pobres, as quais possuem muito menos chances de sobreviver a um aborto clandestino.

A desigualdade substancial entre as mulheres, no que tange à proibição do aborto, revela como ações e políticas específicas geram opressões que fluem na interação entre raça, classe, etnia, sexualidade, etc. As mulheres não estão subordinadas apenas ao seu gênero, mas se encontram em uma posição em que orientação sexual, racismo, xenofobia, classe e gênero se interseccionam. Por meio da teoria da interseccionalidade - que rompe com uma visão monolítica de análise, já que investiga a interação entre opressões simultâneas - é possível identificar as discriminações sofridas por mulheres, que não se encontram em um único eixo de opressão (CRENSHAW, 2002).

As mulheres periféricas, negras e indígenas possuem um acesso mais precário ao planejamento familiar, a contraceptivos, ao pré-natal e às políticas de saúde obstétrica de modo geral. 
Elas são também o grupo mais vulnerável à violência obstétrica e a esterilizações cirúrgicas (DAMASCO; MAIO; MONTEIRO, 2012). Para além da perspectiva dos direitos humanos, as teorias feministas têm advertido que as experiências sexuais e reprodutivas estão sempre situadas em relações de poder, mediante as quais o acesso à informação, aos direitos e às políticas públicas diferem de acordo com o contexto concreto das vidas das mulheres (HARAWAY, 1992). Haraway (1992, p. 95, tradução nossa) mostra como mulheres negras nos Estados Unidos e mulheres de territórios colonizados enfrentam um campo mais amplo de ausência de liberdade reprodutiva: “[...] o problema das mulheres negras nesse contexto não é simplesmente o seu próprio status como sujeitos, mas também o status de seus filhos e de seus parceiros sexuais, homens e mulheres”.

No Brasil, os dados não apenas demonstram que as mulheres negras possuem maior risco de morrer devido a um aborto malsucedido, mas também que são marcadas pelo racismo como estruturante das suas vidas, e, consequentemente, da suposta autonomia e liberdade de decisão sobre ser ou não ser mãe (LIMA; CORDEIRO, 2020). Segundo Lima e Cordeiro (2020, p. 113), “o aborto na vida das mulheres negras significa, em grande parte, uma necessidade imposta por uma série de omissões e violências do Estado, da sociedade e das redes comunitárias”. Ainda, as possíveis consequências de um abortamento inseguro espelham como os sistemas múltiplos de subordinação atingem a vida dessas mulheres.

Como nota Angela Davis (2016, p. 206-207), as mulheres negras e latinas nos Estados Unidos não recorrem ao aborto pela defesa da autonomia do seu corpo e da sua liberdade, assim como defendem majoritariamente as mulheres brancas, mas, antes, pelas difíceis condições de trazer um filho ao mundo. Em termos de movimentos de mulheres, a autora nota que, embora os direitos sexuais e reprodutivos pudessem ter o potencial de unir as feministas de diferentes origens sociais, nos anos de 1970, muitas vezes essa pauta foi atravessada pelo racismo, com o entendimento, por exemplo, de que a legalização do aborto poderia auxiliar na economia e na redução da pobreza. O histórico de esterilizações involuntárias de mulheres negras mostrava a distância das reinvindicações em torno do “controle de natalidade”.

A realidade das esterilizações involuntárias em mulheres negras também é relatada no Brasil, de modo que todo e qualquer debate sobre direitos sexuais e reprodutivos deve levar em conta essa realidade de opressão racial não verificada da mesma maneira sobre corpos de mulheres brancas. Como notam Damasco, Maio e Monteiro (2012), a esterilização cirúrgica chegou a ser o objeto de uma comissão parlamentar mista de inquérito, em 1993, criada pela luta de mulheres como Benedita da Silva e Luiza Barrios. O objetivo era verificar se uma política eugenista, por meio da esterilização em massa, estava em curso no Brasil. Segundo as autoras, o feminismo negro se articulou em torno 
dos debates sobre direitos reprodutivos e foi fundamental para a criação da Lei do Planejamento Familiar (Lei 9.263), de 1996.

Que sentidos serão então decorrentes da criminalização do aborto para essa pluralidade de mulheres? O sistema penal é uma ferramenta de controle social que reproduz e agrava as desigualdades de gênero, raça e sexualidade, ao replicar em suas normativas e ações os estereótipos relacionados ao papel da mulher na sociedade, concebendo o "instinto" materno como uma característica comportamental inerente a elas. Diferentes mecanismos são manejados para manter as mulheres dentro dos padrões impostos de moralidade sexual; entre eles encontra-se o discurso jurídico-penal, o qual reforça a lógica patriarcal, perpetuando o exercício de poder dos homens em relação às mulheres.

\section{DIREITOS, TUTELA DE BENS JURÍDICOS, PUNIÇÃO E MORTE: SENTIDOS PRODUZIDOS NOS DISCURSOS SOBRE A CRIMINALIZAÇÃO DO ABORTO NO BRASIL}

Em 2017, o Partido Socialismo e Liberdade propôs uma Ação de Descumprimento de Preceito Fundamental (de número 442) no Supremo Tribunal Federal (BRASIL, 2018), alegando a não recepção parcial dos artigos 124 e 126 do Código Penal, para excluir do seu âmbito de incidência a interrupção induzida e voluntária realizada nas primeiras 12 semanas da gestação. Assim, caberá ao Supremo Tribunal Federal decidir se essas hipóteses restam configuradas. Com o objetivo de abrir o diálogo com a sociedade civil, o STF convocou duas audiências públicas, realizadas nos dias três e seis de agosto de 2018, para debater a temática do aborto. Foram ouvidos 45 grupos diferentes, os quais representavam organizações das áreas da saúde e dos direitos humanos, entidades religiosas e estudiosos do assunto. Ao todo, foram 61 exposições, tendo em vista que alguns grupos possuíam mais de um representante, com falas de 20 minutos cada, tendo discursado 39 mulheres e 22 homens. Acerca do posicionamento, 18 se pronunciaram contra a ADPF 442 e 43 a favor (BRASIL, 2018).

O objetivo principal deste item é analisar os principais argumentos levantados pelas diferentes partes presentes nas audiências públicas, com foco especial na intervenção penal do Estado para reprimir o aborto. O método de análise foi a Teoria Fundamentada nos Dados (CHARMAZ, 2006), mediante leitura e categorização inicial dos textos, partindo-se então para a elaboração de categorias cada vez mais abstratas, a ponto de gerarem a formulação de hipóteses. Obtendo-se as categorias mais abstratas, realizou-se a discussão dos resultados, mediante a literatura científica do tema. 
A categoria teórica 1) (A criminalização do aborto tem o objetivo de tutelar penalmente o direito à “vida” do "nascituro”) abarca duas principais subcategorias: a) a criminalização do aborto é dever do Estado, pelo reconhecimento dos direitos fundamentais de quem ainda não nasceu, e $\boldsymbol{b}$ ) as funções da penalização da conduta do aborto voluntário por mulheres e homens (terceiros) são b1) a de reprimir e desestimular a prática do aborto voluntário, ainda que dentro das possibilidades legais, e b2) a de comunicar e validar os valores da sociedade brasileira em relação ao direito à vida. A categoria teórica 2) (O direito penal não é o meio adequado para lidar com a questão do aborto) divide-se nas seguintes subcategorias: a) O Estado - laico e democrático - não deve utilizar o direito penal para difundir ideologicamente valores religiosos e patriarcais e para $\boldsymbol{b}$ ) controlar os corpos das mulheres, $\boldsymbol{c}$ ) A criminalização do aborto provoca mortes de mulheres, $\boldsymbol{d}$ ) não evita a sua prática e $\boldsymbol{e}$ ) aprofunda as desigualdades de raça, classe, gênero e sexualidade.

\subsection{A CRIMINALIZAÇÃO DO ABORTO TEM O OBJETIVO DE TUTELAR PENALMENTE O DIREITO À "VIDA” DO “NASCITURO”}

Não é novidade que os setores contrários à descriminalização e à legalização do aborto no Brasil têm se apoiado cada vez mais em argumentos voltados a duas linguagens inspiradas no discurso científico: a linguagem médica e a linguagem dos direitos humanos (BIROLI, 2018; BUDÓ; RODRIGUES; GINDRI, 2020). Interdependentes, enquanto uma se empenha em justificar biologicamente a autonomia do feto em relação ao corpo da mulher, para equipará-lo a uma criança nascida, a outra abraça tal conceito de vida para conceder-lhe direitos também equiparados. Esta categoria foi construída a partir de discursos que se posicionavam contrariamente aos pedidos da ADPF 442, sustentando a criminalização do aborto em funções da pena, na esteira da noção de tutela da vida para legitimar a intervenção penal do Estado.

\subsubsection{A criminalização do aborto é dever do Estado, pelo reconhecimento dos direitos fundamentais de quem ainda não nasceu}

Esta categoria, de forma ampla, resulta da assunção de que: quem ainda não nasceu possui direito à vida desde a concepção, e igualmente a todas as pessoas nascidas; cabe ao direito penal “proteger” esta vida. Nesse sentido, o aborto se equipara ao crime de homicídio, como crime contra a vida, sendo a mulher grávida a autora de autoaborto, correspondendo ao tipo penal do artigo 124 do Código Penal, e quem lhe auxilia na realização de tal desejo sendo autor de "aborto praticado por 
terceiro com o consentimento da gestante”, correspondendo ao tipo penal do artigo 126. A vítima, em ambos os casos, é o feto. Os trechos abaixo exemplificam esta categoria:

Se uma criança tem de ser desconsiderada como pessoa, uma vez que ainda não tem o equipamento mental totalmente desenvolvido, intelectual, valorativo etc., para o mesmo fim; se a criança não tem, o embrião também não o teria. Contudo, damos proteção para ela. Sendo assim, essa afirmação não consegue se sustentar. Nós temos antes que considerar que o início da mais preciosa garantia individual deve ser dado ao lado biológico, cabendo justamente o seu enquadramento (BRASIL, 2018, p. 350).

O desacordo não é jurídico. Desabilitando os já referidos números do Código Penal, este Supremo Tribunal Federal estaria desacreditando na consciência reta que tutela a vida mais frágil e inocente, que é a vida do bebê. O problema é que ninguém quer nominar esse inocente. Ele está apagado, deletado dos nossos discursos, para justificar esse intento em nome da autonomia e liberdade da mulher (BRASIL, 2018, p. 304).

Essas falas resultam do esforço de justificar o motivo pelo qual o direito penal precisa tutelar a “vida” do não nascido. Primeiro, equiparando o embrião com a criança nascida; depois, equiparando o feto com a mãe como sujeito de direitos; por fim, argumentando que o feto é a vida mais "frágil e inocente”, e que, portanto, deveria ser ainda mais legitimamente “protegida” pela lei penal. Na audiência pública da ADPF 442, ambas as linguagens estão presentes, e caminham juntas em relação às representações sociais sobre a natureza do feto, da mulher que aborta e da conduta do abortamento. Os discursos que buscam equiparar o feto a uma criança podem ser exemplificados pelo trecho abaixo:

Eu acho que nós devemos dar esse direito a ele. Eu fico a pensar: "Meu Deus, que coisa a gente pensar em matar uma criança com 12 semanas!” É um embrião, é um feto, na realidade não é mais um embrião, mas faz cortar o coração. Eu, quantas noites passei vendo uma criança, e vejo a minha nação, o meu País se dispor a tirar em massa, extinguir em massa uma criança, a vida de uma criança (BRASIL, 2018, p. 329).

A base para tal equiparação reside na suposta compreensão biológica - com os avanços da ciência - que teria comprovado a autonomia do feto em relação ao corpo da mãe. É o que os trechos abaixo sustentam:

E, olha que coisa linda, os autores enfatizam as propriedades auto - ele é auto - autoorganizacionais do embrião. Ele necessita, sim, da sua mãe para a nutrição, mas ele já vem com o programa dele (BRASIL, 2018, p. 324).

Não digam que não tem sistema nervoso. Todos os elementos de um bebê humano estão formados, e tem apenas $7 \mathrm{~cm}$ de comprimento. Se for uma menina, ela já tem útero. Então, as pessoas dizem: "Eu tenho direito ao meu próprio útero". Eu falo pra elas: "Você, sim, e a sua filha tem direito ao dela” (BRASIL, 2018, 149).

Em termos de representações sociais, o feto aparece como a "vítima ideal” (CHRISTIE, 1986, tradução nossa), já que toda a sua construção se dá em termos abstratos e ficcionais, tendo em 
vista que ele é uma expectativa e, ao contrário do que é dito, depende da mulher para existir. Para além de trazerem a representação do feto como autônomo, esses trechos subentendem a representação da mulher. No primeiro, ela é claramente reduzida a um útero, a um território onde uma função biológica é exercida, a da alimentação e “hospedagem” do feto. A completa ausência de subjetividade da mulher e, portanto, sua objetificação, vem “resolvida” no trecho seguinte, quando à mulher que deseja interromper a gravidez é atribuída uma única possível característica subjetiva: a do egoísmo.

A consequência lógica da defesa desses pressupostos será, então, a de que qualquer forma de interrupção da gravidez - e aí não há limites éticos para casos como o de estupro, por exemplo será uma forma de homicídio. O uso preponderante do verbo "matar” no lugar de "interromper a gravidez”, ou mesmo de “abortar”, torna dramática a consequência que, sustenta-se, é lógica e nada mais. O trecho a seguir dá conta desse padrão: “Aí, por doze semanas de gestação, o princípio fundamental é frontalmente contrário a esse princípio de matar essa criança, porque a gente quer dizer outros nomes, mas não dá sentido se é ‘matar’ mesmo” (BRASIL, 2018, 129).

Outros termos mais chamativos também são utilizados para descrever a conduta: "É assim que o Supremo Tribunal Federal vai garantir a inviolabilidade do direito à vida? Dando uma arma à chamada autonomia, para que homens e mulheres, ao seu bel-prazer, interrompam a vida das crianças até a $12^{a}$ semana, sem precisar dar nenhuma satisfação do seu intento predatório?” (BRASIL, 2018, p. 305). Simultaneamente à utilização da expressão "intento predatório" aparece a representação de seus atores: homens e mulheres que praticam aborto são compreendidos como “predadores”.

Já convertendo o debate à linguagem jurídica, o direito à vida dessas “crianças de até 12 semanas” é posto desproporcionalmente em conflito com a mera "autonomia” das mulheres. O trecho abaixo sintetiza a aliança entre os aspectos biológico e consequências jurídicas.

\begin{abstract}
Podemos citar ainda Rocha, Renata Rocha, "O Direito à Vida e a Pesquisa com Célulastronco”: Não há como negar, genética e embrionariamente, que a nova vida se inicia com a concepção. Tampouco se pode negar a natureza humana desta vida incipiente. Essa constatação é, por si, suficiente para que lhe seja reconhecida a necessidade da outorga de proteção em todas as etapas da vida humana em qualquer momento e onde ela se encontre. Tanto o embrião, como uma criança, não possui capacidade do exercício de contrair obrigações. Mesmo que se queira defender uma espécie de estatuto progressivo no qual a proteção jurídica se amplia na medida em que o embrião se desenvolve, não parece ser a solução, nem tampouco eficaz, no sentido de salvaguarda da vida humana; o que a ciência já demonstrou incontestavelmente, desde a concepção (BRASIL, 2018, p. 349).
\end{abstract}

A tentativa de definir uma linha do tempo a partir da qual é possível afirmar que há vida intrauterina tem sido problemática em vários sentidos, sobretudo porque é baseada meramente em critérios biológicos, os quais não existem sem definições culturais e discursivas. Nos trechos acima, 
a ideia de que a vida inicia com a concepção é sustentada com a finalidade de mascarar argumentos religiosos, o que tem sido uma prática corrente entre cristãos que participam desse debate.

O essencialismo presente no discurso do início da vida está fundamentado em uma concepção meramente biológica de vida humana. Por isso, “[...] ignora os aspectos subjetivos, culturais, sociais e políticos da mãe, ou seja, reconhece na vida humana apenas o aspecto da sobrevivência biológica, ignorando que ela tem uma dimensão subjetiva própria de cada ser humano, um modo peculiar de dar-lhe sentido cultural e socialmente” (ALDANA, 2008, p. 641). A linguagem dos direitos pode ser absolutamente contraproducente nesse sentido, já que a tendência tem sido sempre a de ampliar tal noção em relação ao feto, e reduzi-la em relação à mulher. A ausência da mulher como sujeito de direitos também nesse contexto irá implicar necessariamente a reprodução do velho determinismo: a verdade é que “a proibição de abortar supõe a obrigação de ser mãe” (HOPP, 2012, p. 138, tradução nossa).

Essas manifestações vão ao encontro de projetos de lei e de emenda constitucional que atualmente tramitam no Congresso Nacional, como o Estatuto do Nascituro, para transformar qualquer forma de aborto em crime hediondo, e promovendo "o atendimento e o apoio especial, inclusive financeiro, às mulheres que levem até o final a gravidez resultante de estupro, recebendo um salário mínimo até que a criança complete os 18 anos” (ALDANA, 2008, p. 640). Ao fim e ao cabo, toda a linguagem dos direitos, ainda que expressa pelas vozes dos movimentos de feministas, acaba por redundar em regulação e não em emancipação. Bodelón (2009, p. 105, tradução nossa) nota que, diante do machismo, do autoritarismo e dos modelos econômicos sexistas e desiguais, parece paradoxal falar em direitos das mulheres, concluindo que “os direitos das mulheres não podem ser autênticos direitos sem mudar os fundamentos que construíram o sujeito de direito”.

Do fato de demarcarem a origem da vida na concepção, os opositores do direito ao aborto legal, seguro e gratuito irão propugnar pela manutenção dos efeitos dos artigos do Código Penal que criminalizam o aborto. A base de sustentação da criminalização será, portanto, a noção de que o direito penal tutela bens jurídicos e que a proteção à “vida” de quem não nasceu demanda punição. Isso conduz às subcategorias desenvolvidas abaixo. De todo modo, essa construção dialoga com as funções declaradas da lei penal de uma maneira geral: tutelar os bens jurídicos mais importantes de uma sociedade. Como? Mediante as funções atribuídas de uma maneira geral à pena, conforme a categoria de análise apresentada a seguir. 


\subsubsection{A criminalização do aborto voluntário por mulheres e homens possui funções dissuasórias, simbólicas e integrativas}

Uma parcela significativa de especialistas que defende o não acolhimento da ADPF 442 alega que, caso o aborto seja descriminalizado, haverá um consequente aumento no número de abortos praticados. Estes são alguns exemplos de falas nesse sentido: “E aí vem mais uma das falácias, a de que aborto diminui quando é legalizado. Gente, isso foge até ao senso comum, isso não tem lógica! Se você legaliza, aumenta” (BRASIL, 2018, p. 81); “O primeiro desdobramento direto da legalização do aborto nessas outras nações foi o aumento do número de abortos realizados” (BRASIL, 2018, p. 210); "Em todos esses países o aborto foi legalizado. Praticam até três a vinte e três vezes mais abortos que o Brasil” (BRASIL, 2018, p. 314).

Essa alegação parte do pressuposto de que as pessoas de fato deixam de praticar condutas simplesmente porque são elas proibidas, em abstrato, pela lei penal. De acordo com Andrade (2012), trata-se da crença de que, ao se criminalizar uma prática, o objetivo da prevenção pela dissuasão estará garantido, economizando "vidas”. O temor da lei seria, assim, um resultado dado como garantido, sem considerar aspectos fundamentais que a sociologia e a criminologia têm demonstrado. Primeiro, que a cifra oculta da criminalidade é muito maior do que os casos registrados, de modo que, quando proibida uma conduta, mais distantes estarão as estatísticas da realidade. Segundo, que as pessoas não temem a lei da mesma forma, pois a vulnerabilidade perante o sistema de controle penal é absolutamente distinta em razão da seletividade estrutural pela raça, classe, gênero, sexualidade, etc. (ZAFFARONI et al., 2003). Terceiro, se os dados sobre aborto não são confiáveis, pois praticado na clandestinidade, não é possível aferir empiricamente se as mulheres estão deixando de praticá-lo por medo da punição.

De fato, mesmo em relação à aplicação da lei penal, é fácil verificar que no âmbito da criminalização secundária, aquela que ocorre na ação das agências executivas e judiciais do sistema penal (ZAFFARONI et al., 2003), há proporcionalmente poucos processos penais instaurados pela prática de aborto. Isso, inclusive, foi constatado por um dos especialistas que se posicionou contra a ADPF 442, demonstrando como o sistema penal falha, também, nas suas funções declaradas. Nas palavras do médico Raphael Câmara: “Ninguém vai preso por aborto no Brasil! De 2000 a 2017, na Defensoria Pública do Rio de Janeiro, só 42 mulheres foram processadas, nenhuma foi presa. Eu não conheço ninguém que tenha sido preso” (BRASIL, 2018, p. 80).

Sobre essa questão, a discussão em torno do número de abortos praticados antes e depois da descriminalização/legalização é bastante difícil de se precisar, pois, além de ser uma prática criminalizada, há questões psicológicas, morais, religiosas, culturais, que interferem na decisão das 
mulheres de admitirem ou não a prática (OSIS et al., 1996, p. 445). Isso faz com que os dados coletados por meio de pesquisas não correspondam à realidade. Também se aproveita dessa dificuldade quem se posiciona contrariamente à descriminalização, como o Padre José Eduardo:

Ora, os dados do SUS apontam haver 200 mil internações por aborto, por ano. A estimativa dos médicos experientes é de que destes no máximo 25\% seriam por abortos provocados. Numerosas pesquisas apontam valores entre 12\% e 25\%. Em 2013, o IBGE estimou que o número de abortos naturais corresponde a sete vezes o número de provocados. [...] Então, no máximo, há 100 mil abortos provocados por ano no Brasil. Os números, que foram aqui apresentados, são 10 ou mais vezes maiores do que a realidade. Toda essa inflação é para poder concluir que, onde se legalizou a prática, realizaram-se menos abortos do que no Brasil (BRASIL, 2018, p. 312-313).

A pesquisa feita pelo Instituto Brasileiro de Geografia e Estatística (IBGE) foi realizada por meio de entrevistas face a face com entrevistadores de ambos os sexos, o que, segundo Diniz, Medeiros e Madeiro (2017, p. 654), pode desencadear uma subnotificação ${ }^{1}$ muito significativa. Da mesma forma, a pesquisa intitulada "Dificuldades para obter informações da população de mulheres sobre aborto ilegal” constatou que as mulheres tendem a omitir a informação sobre prática de aborto quando perguntadas diretamente sobre o assunto. Ainda sobre essa pesquisa: "das nove mulheres cujos registros no hospital eram de aborto espontâneo, na entrevista uma declarou que tivera um aborto provocado enquanto outra negou qualquer aborto, o que faz pensar que, provavelmente, aquele que estava registrado no hospital fora na verdade provocado” (OSIS et al., 1996, p. 449-450). Assim, a pesquisa mostra que uma em cada cinco mulheres, aos quarenta anos, já fez pelo menos um aborto na vida, e que "o número de mulheres que o fizeram somente no ano de 2015 seria de aproximadamente 503 mil” (DINIZ; MEDEIROS; MADEIRO, 2017, p. 656)².

Associado à questão da subnotificação está o problema de que o conhecimento sobre esses casos ocorre geralmente por conta de internações em hospitais, resultantes de complicações. Isso implica que as pessoas que serão efetivamente perseguidas pelo sistema penal serão apenas as mais vulneráveis a ele, e que se submeterem ao procedimento de aborto mediante práticas inseguras e menos custosas, o que será tratado na análise da próxima categoria. Assim, a única finalidade que supostamente restaria, para quem defende a utilização do sistema penal como reprimenda da prática de abortos, seria a simbólica.

1 A técnica utilizada para a pesquisa referida pode produzir subestimação da magnitude do aborto em razão de não possuir a garantia do sigilo, diferentemente de estudos que se utilizam da técnica da urna, referida nos estudos realizados por Diniz, Medeiros e Madeiro (2017).

2 Esses são os dados da Pesquisa Nacional sobre Aborto, estudo que foi feito por meio da técnica de urna, com cédulas anônimas. A pesquisa não cobriu $17 \%$ das mulheres não alfabetizadas, bem como as adolescentes (com menos de 18 anos) e as mulheres com mais de 39 anos, as quais não foram entrevistadas, de modo que os dados também podem conter subnotificação (DINIZ; MEDEIROS; MADEIRO, 2017, p. 656). 
Mas de qual simbolismo se fala quando se trata da criminalização do aborto, dado o contexto do embate colocado? Trata-se da possibilidade de punição de mulheres que, grávidas, não querem ser mães. É, portanto, uma reafirmação dos valores sociais burgueses a respeito do lugar da mulher na sociedade, associada à compreensão de setores religiosos ligados também à função materna e à origem da vida. Os trechos abaixo exemplificam essa ideia:

Indiscutivelmente a prática do abortamento é ato reprovável para a maioria da sociedade brasileira. Revela o Censo de 2010 que mais de 85\% dos brasileiros professam a fé cristã. E o ato de tirar a vida de outrem, seja de um embrião, feto, criança, jovem, adulto, idoso, saudável ou doente, é atentado a lei da ética e da moral cristã pois viola o sexto mandamento do decálogo bíblico que diz “não cometerás assassinato” (BRASIL, 2018, p. 334).

A questão jurídica dos números 124 e 126 foi recepcionada, sim, por todas as mães que pensaram em abortar, mas não o fizeram, lembrando que é um atentado contra a vida. Se negarmos isso, negaremos a capacidade de discernimento de todas as mulheres que optaram por não abortar para salvaguardar os seus filhos (BRASIL, 2018, p. 304).

A função de prevenção-integração parte exatamente do pressuposto de que a pena deve servir à confirmação dos valores dominantes de uma sociedade, com o fim de mantê-la em equilíbrio. É uma leitura que se encaminha para o conservadorismo, já que entende a punição como um meio para a obtenção da tranquilidade da sociedade, independentemente do cumprimento de funções instrumentais, como, por exemplo, a redução do número de abortos. A função da punição seria a de possibilitar a reafirmação da validade das normas sociais, por meio da punição (BARATTA, 2004).

No caso da criminalização do aborto, a política criminal tem como propósito corroborar um modelo de mulher-mãe, sendo ela a responsável pelos cuidados domésticos e das crianças, desempenhando um trabalho contínuo e não remunerado. Acontece que mesmo não havendo a comprovação de que as mulheres se sintam inibidas a interromperem suas gestações em razão de um temor da pena, o Estado está ciente dos inúmeros recursos que podem prevenir uma gravidez indesejada (informações sobre saúde reprodutiva, anticoncepção, educação sexual e planejamento da gravidez). E apesar de existirem políticas públicas com tais finalidades, na prática há um maior acesso à saúde por uma parcela de mulheres e um menor acesso a outras, sendo essa ausência/presença uma representação evidente do biopoder do Estado.

A regulação do aborto nesses termos não é tanto ou principalmente uma política criminal que visa prevenir danos ou defender a sociedade, mas sim uma medida de controle social que atribui uma subjetividade às mulheres, modelando nossas aspirações, possibilidades de vida, comportamentos e sexualidades, mediante o controle de nossos corpos (HOPP, 2012, p. 142143, tradução nossa).

Exigir fidelidade à norma pressupõe a ausência de questionamentos macroestruturais ligados ao direito penal: o fato de as normas na sociedade capitalista serem instrumento de dominação de 
classe; as características de sociedades patriarcais que usam o direito para subjugar as mulheres; o racismo estrutural que oprime e retira o acesso à saúde reprodutiva às mulheres negras e indígenas; a pluralidade cultural interna às sociedades em seus valores e crenças e a relatividade do direito penal, etc.

Por outro lado, a punição em sentido lato, que inclui a reprovação social da prática de aborto, a violência institucional praticada nos hospitais quando chegam mulheres precisando de atendimento após uma tentativa malsucedida de aborto, e o próprio processo penal, que, em si, é uma pena, transforma a mulher em bode expiatório, em um meio para se atingir o fim maior que é o do controle sobre seu corpo e o sentido de reafirmação social dos mesmos valores que a oprimem. À função simbólica de reiterar os valores de subjugação das mulheres em uma sociedade patriarcal, adicionase o descumprimento de qualquer função instrumental, do ponto de vista da proteção da vida.

\subsection{A CRIMINALIZAÇÃO DO ABORTO NÃO PREVINE A PRÁTICA DO ABORTO E MATA MULHERES}

A ideia de que a laicidade do Estado deve permear o debate sobre o aborto é a base desta categoria, pois parte justamente do questionamento a respeito dos limites da atuação estatal, tanto para restringir quanto para promover os direitos das mulheres. Nesse sentido, questionando a atuação recente do Parlamento, falou Natália Mori Cruz, pelo coletivo Margarida Alves:

A defesa da laicidade e a efetiva separação entre Estado e Igreja são fundamentais para o funcionamento da democracia e para a garantia da igualdade e da liberdade, inclusive de culto. A articulação de grupos religiosos no Parlamento brasileiro tem se traduzido na tentativa cada vez mais forte de retroceder nos direitos conquistados pelas mulheres e estancar qualquer movimento de avanço no sentido da igualdade e da nossa autonomia (BRASIL, 2018, p. 236).

Ainda que minoritárias, houve manifestações nesse sentido por parte de representantes religiosas. O movimento Católicas pelo Direito de Decidir, representado pela doutora Maria José Fontelas Rosado-Nunes, posicionou-se a favor da laicidade do Estado, questionando a concepção de vida: "E constitui evidente má-fé tratar como bebê, como criança, como pessoa, o que é um zigoto, um embrião ou mesmo um feto, no início da gestação” (BRASIL, 2018, p. 404).

Se o dissenso está presente na comunidade religiosa sobre a temática, algumas falas demonstraram que isso não é diferente na ciência. Helena Bonciani Naves falou como representante da Sociedade Brasileira para o Progresso da Ciência (SBPC) sobre o tema:

Embriologistas podem dizer que a fecundação ou a fertilização é o momento chave do desenvolvimento; outros definem o início da vida a partir da implantação do embrião e de 
boas probabilidades de viabilidade, que ocorreriam a partir do $14^{\circ}$ dia [...] Os avanços científicos no campo da fertilização in vitro ilustram bem como a resposta para a questão sobre o início da vida humana não está na ciência (BRASIL, 2018, p. 92).

Na prática, trata-se de admitir que qualquer definição será arbitrária, já que o significado da vida não é algo que pode ser abstraído da cultura e dos atravessamentos de poder de definição. Do campo jurídico, a necessidade de coerência dessa concepção sobre tutela da vida e direitos do nascituro no ordenamento jurídico aparece como outra categoria. É a contribuição de Cristina Telles, representante da Clínica UERJ de Direitos:

[...] tratar o embrião ou feto como pessoa humana, já titular de direitos fundamentais, é ignorar as normas que existem sobre a reprodução assistida, sobre pesquisa com célula-tronco e sobre o próprio aborto, que não tem a mesma pena do crime de homicídio. É ignorar também as razoáveis e distintas valorações morais sobre o início da vida. Hoje pela manhã, nós vimos representantes de diferentes religiões valorando de modo distinto o início da vida (BRASIL, 2018, p. 600).

Ocorre que tratar, a problemática do aborto, a partir de uma perspectiva moral desencadeia diversos entraves sociais, pois não há como estabelecer um consenso moral, a partir de um debate democrático. As compreensões morais se processam de diversas formas, seja por influência da família, da mídia, da escola, “o que acaba por mesclar princípios e crenças inicialmente inconciliáveis” (DINIZ; ALMEIDA, 1998, p. 132).

As consequências jurídicas, portanto, das controvérsias relativas ao momento em que surge a vida que deve ser tutelada, são, sob essa perspectiva, pensadas a partir de outros campos que não o do direito penal. $\mathrm{O}$ argumento do minimalismo penal do ponto de vista político-criminal aparece na fala da representante da Clínica de Direitos Humanos da Universidade Federal de Minas Gerais, Camila Silva Nicácio, e da representante da Clínica UERJ de Direitos, Cristina Telles, respectivamente:

Para a melhor doutrina, conforme os princípios regentes do Direito Penal brasileiro, a criminalização primária ou secundária deve ser sempre a última via a ser empregada para solucionar determinado conflito ou tutelar um bem jurídico. Ademais, o princípio da ultima ratio pode ser depreendido de nossa própria Constituição, a partir do estabelecimento do Estado democrático de Direito no Brasil (BRASIL, 2018, p. 584).

$[\ldots]$

É, como colocada aqui, em face da possível dúvida, pesa, em favor da descriminalização, a subsidiariedade do Direito Penal. É preciso tolerar quem pensa de modo diferente. Numa disputa divisível como essa, moralmente divisível, o papel do Estado não pode ser criminalizar um dos lados (BRASIL, 2018, p. 603).

A segunda fala acima traz à tona o discurso dos direitos das mulheres agora ultrapassando aquela noção de egoísmo por detrás das críticas religiosas à autonomia da mulher, compreendendo $a$ 
necessidade de não se criminalizar um dos campos de debate, pois isso atingiria em cheio a própria democracia.

Além disso, o discurso dos direitos das mulheres se reconfigura quando ele se amplia, $d a$ perspectiva da autonomia como direito individual, para também alcançar o direito social à saúde. Este direito estaria sendo violado - desigualmente - com a criminalização do aborto. O representante do Centro de Pesquisas em Saúde Reprodutiva de Campinas (CEMICAMP), José Henrique Rodrigues Torres: “[...] a criminalização do aborto é absolutamente incompatível com a garantia de assistência plena à saúde e à vida das mulheres, além de violar os direitos das mulheres à autonomia, à autodeterminação, à igualdade e à dignidade” (BRASIL, 2018, p. 95).

Diretamente em relação aos objetivos da intervenção penal na questão do aborto, esta categoria inclui o papel do sistema penal no controle da prática de abortos inseguros, mas com um raciocínio divergente da categoria anterior. Em primeiro lugar, prevalece nos discursos inseridos nesta grande categoria a questão da subnotificação, demonstrando que os números de abortos registrados estão muito aquém da realidade. Esse dado, que se traduz no discurso criminológico em cifra oculta, produz consequências lógicas no sentido dos objetivos instrumentais da intervenção penal: a criminalização não previne a prática de abortos. Ilustram essa categoria os trechos abaixo, respectivamente, das expositoras Eleonora Nacif, representante do Instituto de Ciências Criminais, e Charlene da Silva Borges, representante da Defensoria Pública da União:

Percebe-se, portanto - quase encerrando -, que a criminalização e a aplicação do Direito Penal não impedem a prática de abortos, tampouco percebe-se a redução do número de tais procedimentos e têm efeitos graves sobre os direitos fundamentais e da vida das mulheres meninas e adolescentes (BRASIL, 2018, p. 521).

[...]

Os dados demonstram que o Direito Penal não inibe o comportamento eivado de ilicitude que é a escolha por interromper uma gravidez indesejada. Na prática e na realidade factual, essa decisão continua a ser tomada mesmo no contexto inseguro de criminalização, tamanha é sua relevância na vida da mulher (BRASIL, 2018, p. 526).

A parte final da fala introduz a próxima categoria: a criminalização do aborto provoca violações de direitos das mulheres, colocando em risco as suas vidas. Conforme dados do Departamento de Informática do Sistema Único de Saúde do Brasil (DATASUS), no ano de 2017, houve 67 registros de mulheres que morreram em decorrência de abortos, incluindo-se aborto espontâneo, outros tipos de aborto, aborto não especificado e falha de tentativa de aborto (BRASIL, 2017). Foram abarcadas todas essas modalidades, pois até mesmo quando o médico faz o preenchimento do campo no momento da morte pode haver imprecisão na definição quanto ao aborto ter sido provocado ou espontâneo, pois, muitas vezes as mulheres não contam ao médico atendente o 
que realmente aconteceu, o que decorre principalmente da criminalização, ou seja, do medo de serem denunciadas por esses profissionais. Apesar da previsão de confidencialidade entre a paciente e o médico, conforme consta no Código de Ética Médica (Resolução n ${ }^{\circ} 1.931$, de 17 de setembro de 2009, do Conselho Federal de Medicina), existem notícias demonstrando que esse dever não é sempre cumprido (BRASIL, 2018, p. 191-192).

Há outros pontos bastante delicados e importantes de se analisar quando se trata de dados sobre a interrupção voluntária da gravidez. Conforme a representante do Ministério da Saúde na audiência pública, Maria de Fátima de Souza, o número que a Secretaria de Vigilância em Saúde (SVS) encontrou de mortes por abortos inseguros, no ano de 2016, foi de 203. O dado não é o mesmo do DATASUS, que informa serem 55 as mortes, das quais 31 mortes foram de mulheres negras, e 20 de mulheres brancas (BRASIL, 2016b), porque algumas mortes maternas não são classificadas como tais na declaração de óbito. A justificativa seria a de que o DATASUS não é responsável por investigar as reais causas das mortes, mas apenas por classificá-las de acordo com o que está posto na certidão de óbito (BRASIL, 2018, p. 188-189).

A SVS, por outro lado, é o órgão responsável por analisar o que efetivamente levou a essas mortes, para estabelecer políticas públicas que sejam efetivas. Maria de Fátima de Souza explicou como se coletam os dados:

\begin{abstract}
Nesse sistema, nós coletamos, então, a morte, o que causou a morte. Só que, o que causa morte, eu tenho o que causa imediatamente a morte e a causa básica da morte. Então, por exemplo, uma morte materna pode se dar por uma causa imediata, por uma infecção generalizada, que foi o caso que eu trouxe, que leva [a] um choque séptico, mas que foi causada, como causa básica, por um aborto inseguro. [...] Então, no sistema, nós temos uma sequência de causas que levam à causa final, à causa imediata da morte. Mas o que interessa para saúde pública é a causa básica da morte, que é onde nós vamos atuar para prevenir futuras mortes (BRASIL, 2018, p. 183-184).
\end{abstract}

Ao associarem as diferentes pesquisas que buscam identificar qual é a realidade dos abortos no Brasil, bem como das mortes ocasionadas por abortos inseguros, esses discursos irão chegar em um ponto essencial: se o aborto está presente em todas as classes sociais e é muito mais frequente do que os dados do sistema de saúde e do sistema de justiça criminal apresentam, então, como a criminalização afeta as mulheres? Se o sistema penal não tem condições de e não deseja investigar, processar e penalizar todas as mulheres que praticam todos os abortos, para que serve a criminalização? Andrade (2012) demonstra que dois fatores principais devem ser considerados para se pensar a operacionalidade real do sistema penal: o sistema penal jamais daria conta de investigar todos os crimes que são cometidos diariamente, até porque isso causaria uma catástrofe social, de modo que o sistema está estruturado para não operar em toda a sua extensão; a criminalização 
acontece de forma desigual entre as pessoas, havendo uma seletividade de acordo com o status social dos envolvidos.

E é essa a realidade da penalização do abortamento, tendo em vista que não só as mulheres negras/pardas e pobres são as que mais morrem, como são as que mais sofrem a repressão estatal, sendo a "clientela penal” não apenas do aborto, mas da maior parte dos tipos de crime que chegam ao sistema penal. Foi o que constatou uma pesquisa feita pela Advocacia Cidadã pelos Direitos Humanos (Advocaci), a partir das informações constantes nos dados cadastrais da Assistência de Estatística Administrativa e Criminal da Polícia Civil do Estado do Rio de Janeiro (Asplan), da Central de Inquéritos do Ministério Público do Estado do Rio de Janeiro e por meio de trabalho de campo (EMMERICK, 2007, p. 148). Mediante os dados da Asplan foram encontrados 260 registros de ocorrência pelo crime de autoaborto no período de janeiro de 2000 a janeiro de 2004, sendo, na grande maioria, mulheres negras e pobres - das ocorrências em que havia informações sobre o perfil da investigada, pois nem sempre esse campo é preenchido no registro. Porém, segundo os dados da Central de Inquéritos do Ministério Público do Estado do Rio de Janeiro, apenas 22 mulheres foram efetivamente denunciadas pelo órgão entre 2005 e 2017 (RIO DE JANEIRO, 2017, p. 24). Com a pesquisa de campo, detectaram-se 11 processos, averiguando-se que as mulheres pertencentes aos grupos historicamente marginalizados (negras, pobres e com baixa escolaridade) são as mais processadas (EMMERICK, 2007, p. 149).

A categoria a criminalização do aborto aprofunda as desigualdades de raça, classe, gênero e sexualidade pode ser exemplificada, inicialmente, no debate sobre estereótipos de gênero. De acordo com Rayani Mariano dos Santos (2015, p. 13), a defesa do direito à interrupção voluntária da gravidez não está associada à desvalorização do feto, mas à noção de que a maternidade não pode ser compulsória, inclusive, porque métodos anticoncepcionais podem vir a falhar. Nesse sentido discursou a representante da Associação Brasileira de Antropologia (ABA), Lia Zanotta:

Por isso, no caso do aborto, o estigma é produzido por um complexo formado e reafirmado por religião, moral e lei, que impõe, sobre o corpo das mulheres, a expectativa de que toda a gravidez resulte em um parto, que todas as mulheres devem ser compulsoriamente mães e o mais inocente, senão perverso para a compreensão antropológica - de que haveria uma natureza feminina a ser conformada pela lei (BRASIL, 2018, p. 222).

Os discursos incluem ainda a noção de que a criminalização do aborto aprofunda as desigualdades entre homens e mulheres. A maternidade compulsória não está associada à paternidade compulsória no contexto da intervenção penal do Estado. O discurso de Lívia Gil Guimarães auxilia na compreensão desta categoria: 
Enquanto as mulheres não têm escolha, a opção do homem por não assumir as responsabilidades típicas da paternidade é socialmente considerada como algo natural. Tanto é assim que é grande a proporção de crianças que sequer possuem o nome do pai na certidão de nascimento - 5,5 milhões segundo o Censo Escolar feito pelo Inep em 2011 (BRASIL, 2018, p. 611).

Por fim, o discurso sobre as desigualdades operadas pelo racismo aparece também em várias manifestações, e pode ser ilustrado na fala da advogada Lívia Gil Guimarães, do Núcleo de Prática Jurídica em Direitos Humanos da USP: “Com a criminalização, a escolha por abortar ou não acaba sendo um privilégio privado de mulheres brancas e afortunados, demarcando uma desigualdade entre mulheres, relegando às negras, pobres e indígenas uma cidadania de segunda classe” (BRASIL, 2018, p. 610).

Mais fundamentalmente voltada à explicação das consequências da criminalização nos corpos das mulheres negras é a fala de Fernanda Lopes, representante do coletivo Criola: “O aparato disciplinador e os elementos usados para disciplinar o corpo da mulher negra são diferentes em relação às demais, porque estes corpos, porque os nossos corpos, supostamente, são corpos que se pode deixar morrer" (BRASIL, 2018, p. 241, grifo nosso). Aqui, a autora do discurso, após falar sobre laqueadura compulsória dirigida a mulheres negras e sobre os riscos duplicados de mortes de mulheres negras em razão de abortos malsucedidos, apontou para uma função real do sistema penal brasileiro, que tem sido denunciada há décadas pelo movimento negro: o do genocídio movido pelo próprio Estado (FLAUZINA, 2008).

Ao criminalizar a prática do aborto, todas as mulheres são atingidas, já que restam impedidas de exercer plenamente seus direitos. Porém, o racismo estrutural tem operado de tal maneira que historicamente as mulheres negras têm sofrido essa repressão de maneira ainda mais grave, sendo não só a principal clientela do sistema criminal, como também as que têm mais probabilidade de virem a ser vítimas fatais de um aborto inseguro, o que decorre também da falta de acesso às políticas de saúde sexual e reprodutiva (LIMA; CORDEIRO, 2020). A fala de Fernanda Lopez, pelo coletivo Criola, não apenas sintetiza a ideia, como abre um caminho interpretativo fundamental para pensar as funções reais da criminalização do aborto - o corpo das mulheres como território de dominação.

\footnotetext{
A penalização do aborto evidencia que o corpo e a vida das mulheres são espaços a serem dominados. Os territórios de maior incidência de dominação são os corpos femininos negros e pobres e de outras mulheres que compõem outros grupos historicamente discriminados. Nós somos estas mulheres que, para além de uma menor possibilidade de fazer uma gestão de riscos, menos recorremos às instituições que poderiam nos proteger, dado que a prática é penalizada. [...] E para nós, mulheres negras, a vivência do racismo impede o exercício dos nossos direitos, em especial, mas não exclusivamente, dos nossos direitos reprodutivos, quer seja na escolha de termos filhos, quer seja na possibilidade de vê-los crescer de forma segura, ou na realização de aborto sem risco (BRASIL, 2018, p. 238-239).
} 
Os discursos incluídos nesta categoria evidenciam que as funções atribuídas à criminalização do aborto não somente são descumpridas, como são invertidas na prática (ANDRADE, 2012), provocando mortes ao invés de preveni-las; violando direitos a pretexto de protegê-los; defendendo a hegemonia burguesa racista na concepção sobre o papel da mulher em vez de proteger propriamente a vida de quem quer que seja. Para além disso, as funções reais da criminalização do aborto parecem ser, de um lado da moeda, o controle das mulheres que desejam abortar, obrigando-as a cumprir a maternidade compulsória (BIROLI, 2018, p. 112), ou a arriscar suas vidas, conforme sua posição nas diferentes intersecções de opressões; e, do outro lado da mesma moeda, prevalece uma função simbólica de reafirmação de valores, sejam eles vinculados à ideologia burguesa patriarcal, sejam eles propriamente ligados ao aprofundamento de crenças religiosas cristãs como amálgama das relações sociais.

\section{CONCLUSÕES}

Com base nos dados encontrados e na literatura analisada, foi possível perceber que ainda são reproduzidos os estereótipos de gênero, nos quais a mulher é concebida como um ser determinado biologicamente à maternidade. Diferentes recursos são utilizados para mantê-las nesse papel, estando, entre eles, o sistema penal, que não só auxilia no controle da sexualidade feminina, como também reforça as desigualdades entre as mulheres.

Por meio dos estudos de gênero, a vivência daquelas destinadas à função de mãe passou a repercutir não só nos debates científicos, mas na esfera pública de um modo geral. As teorias feministas desmistificaram a concepção de que ser mulher é uma condição biológica inerente ao sexo, quando, na verdade, trata-se de uma construção em que o machismo e o racismo estruturais permeiam as definições dos lugares de homens e mulheres, de brancas, negras, indígenas; de heterossexuais, lésbicas cis e transgêneros. Criminalizar o aborto é uma forma de subordinar o projeto de vida de todas as mulheres, penalizando aquelas que fogem dos padrões impostos pelas diferentes estruturas.

Nesse sentido, o principal embate travado nas audiências públicas da ADPF 442 ocorreu em torno dos efeitos da criminalização no número de abortamentos. Os resultados encontrados apontaram para duas grandes cadeias lógicas de argumentos que ensejaram a elaboração de categorias. Ambas as categorias partem de pressupostos sobre a representação da mulher, do feto, da conduta do aborto, bem como das funções exercidas pela criminalização. A primeira categoria construída é a de que: a criminalização do aborto tem o objetivo de tutelar penalmente o direito à “vida” do “nascituro”, e é dever do Estado, pelo reconhecimento dos direitos fundamentais de quem ainda não nasceu. As 
funções da penalização da conduta do aborto voluntário por mulheres e homens (terceiros) são a de reprimir e desestimular a prática do aborto voluntário, ainda que dentro das possibilidades legais; a de comunicar e validar os valores da sociedade brasileira em relação ao direito à vida. A segunda categoria foi elaborada assim: o direito penal não é o meio adequado para lidar com a questão do aborto, pois o Estado - laico e democrático - não deve utilizar o direito penal para difundir ideologicamente valores religiosos e patriarcais e para controlar os corpos das mulheres. A criminalização do aborto provoca mortes de mulheres, não evita a sua prática, e aprofunda as desigualdades de raça, classe, gênero e sexualidade.

Apesar de os discursos produzidos nessa segunda categoria terem sido mais presentes e numerosos nas audiências públicas, é possível afirmar que eles são contra-hegemônicos, se levado em consideração o contexto do conservadorismo político no Brasil, nos três poderes. Trata-se, portanto, de um debate que, para além da linguagem dos direitos, perpassa necessariamente o reconhecimento coletivo da necessidade de superação de uma estrutura patriarcal, racista e economicamente opressora, algo que apenas com a ADPF 442, ainda que julgada procedente, não se modificará.

A luta das mulheres ensejou a possibilidade de que a questão chegasse ao STF, mas certamente é por essas lutas, e não pela atuação do STF, que essas estruturas poderão ser superadas. A capacidade de domesticação da linguagem dos direitos mediante o próprio direito demonstra o quanto reside na radicalidade a possibilidade de se alcançar a superação dessas estruturas.

\section{REFERÊNCIAS}

ALDANA, Myriam. Vozes Católicas no Congresso Nacional: aborto, defesa da vida. Estudos Feministas, [s. l.], v. 16, n. 2, p. 639-646, 2008. Disponível em: https://bit.ly/2QDDZLR. Acesso em: 8 mar. 2021.

ANDRADE, Mailô de Menezes Vieira. Perspectivas feministas em criminologia: a interseccionalidade entre gênero, raça e classe na análise do estupro. Revista Brasileira de Ciências Criminais, [s. l.], n. 146, p. 435-455, 2018.

ANDRADE, Vera Regina Pereira de. A soberania patriarcal: o sistema de justiça criminal no tratamento da violência sexual contra a mulher. Seqüência, [s. l.], v. 26, n. 50, p. 71-102, jul. 2005.

ANDRADE, Vera Regina Pereira de. Pelas mãos da criminologia. O controle penal para além da (des)ilusão. Rio de Janeiro: Revan, 2012.

BARATTA, Alessandro. Criminologia Crítica e Crítica do Direito Penal. Introdução à sociologia do Direito Penal. 6. ed. Tradução Juarez Cirino dos Santos. Rio de Janeiro: Revan, 2011. 
BARATTA, Alessandro. Integración-Prevención: Una “Nueva” Fundamentación de la Pena Dentro de la Teoría Sistémica. In: ELBERT, Carlos Alberto (dir.). Criminología y sistema penal. Compilación in memoriam. Montevideo: B de f, 2004. p. 1-30.

BARATTA, Alessandro. O paradigma do gênero: da questão criminal à questão humana. In: CAMPOS, Carmen Hein de (org.). Criminologia e feminismo. Porto Alegre: Sulina, 1999. p. 1980.

BIROLI, Flávia. Gênero e desigualdades: limites da democracia no Brasil. São Paulo: Boitempo, 2018.

BODELÓN, Encarna. Feminismo y derecho: mujeres que van más allá de lo jurídico. In: NICOLÁS, Gemma et al. (comp.). Género y dominación: críticas feministas al derecho y al poder. Barcelona: Anthropos, 2009. p. 95-116.

BRASIL. Ministério da Saúde. DATASUS. Óbitos de Mulheres em idade fértil e óbitos maternos. 2017. Disponível em: https://bit.ly/3vBGq0r. Acesso em: 8 mar. 2021.

BRASIL. Ministério da Saúde. DATASUS. Óbitos de Mulheres em idade fértil e óbitos maternos (cor/raça). 2016b. Disponível em: https://bit.ly/3npPvGB. Acesso em: 8 mar. 2021.

BRASIL. Ministério da Saúde. Gabinete do Ministro. Portaria n 2.282, de 27 de agosto de 2020. Dispõe sobre o Procedimento de Justificação e Autorização da Interrupção da Gravidez nos casos previstos em lei, no âmbito do Sistema Único de Saúde-SUS. Diário Oficial da União: seção 1, Brasília, DF, ed. 166, p. 359, 28 ago. 2020. Disponível em: https://bit.ly/2R7Lgna. Acesso em: 8 mar. 2021.

BRASIL. Supremo Tribunal Federal. Argüição de Descumprimento de Preceito Fundamental 54 Distrito Federal. Relator: Ministro Marco Aurélio. Data do julgamento: 12 abr. 2012. Disponível em: https://bit.ly/32ZwGQZ. Acesso em: 8 mar. 2021.

BRASIL. Supremo Tribunal Federal. Audiência pública. Interrupção voluntária da gravidez. ADPF 442. Relatora Ministra Rosa Weber [transcrição]. Brasília, DF: Supremo Tribunal Federal, ago. 2018. Disponível em: https://bit.ly/3sR6QcA. Acesso em: 8 mar. 2021.

BRASIL. Supremo Tribunal Federal. Habeas Corpus $n^{0}$ 124.306 Rio de Janeiro. Relator: Ministro Marco Aurélio. Data do julgamento: 29 nov. 2016a. Disponível em: https://bit.ly/3vnUz0R. Acesso em: 8 mar. 2021.

BUDÓ, Marília de Nardin; RODRIGUES, Cristina Carla; GINDRI, Eduarda Toscani. Political discourse on abortion in Brazil's Parliament: the invisibility of women's rights. Oñati Socio-Legal Series, [s. l.], v. 10, n. 1S, p. 67-99, 2020. Disponível em: https://bit.ly/3xCbyPd. Acesso em: 8 mar. 2021.

CAMPOS, Carmen Hein de. Criminologia feminista: teoria feminista e crítica às criminologias. Rio de Janeiro: Lumen Juris, 2017. 
CAPPI, Riccardo. A “teorização fundamentada nos dados”: um método possível na pesquisa empírica em Direito. In: MACHADO, Maíra Rocha (org.). Pesquisar Empiricamente o Direito. São Paulo: Rede de Estudos Empíricos em Direito, 2017. p. 391-422.

CHARMAZ, Kathy. Constructing grounded theory: A practical guide through qualitative analysis. London: Sage, 2006.

CHRISTIE, Nils. The Ideal Victim. In: FATTAH, E. A. (ed.). From Crime Policy to Victim Policy. London: Palgrave Macmillan, 1986. p. 17-30. Disponível em: https://bit.ly/3t1COTn. Acesso em: 8 mar. 2021.

COSTA, Lara Paula de Meneses. A descriminalização do aborto sob a perspectiva da criminologia crítica e a necessidade de regulação dos direitos sexuais e reprodutivo das mulheres. 2018. 72 p. Monografia (Graduação em Direito) - Universidade Federal do Ceará, Fortaleza, 2018.

CRENSHAW, Kimberle. Demarginalizing the Intersection of Race and Sex: A Black Feminist Critique of Antidiscrimination Doctrine, Feminist Theory and Antiracist Politics. University of Chicago Legal Forum, [s. l.], v. 1989, n. 1, p. 139-167. Disponível em: https://bit.ly/3eBfFlJ. Acesso em: 8 mar. 2021.

CRENSHAW, Kimberlé. Documento para o encontro de especialistas em aspectos da discriminação racial relativos ao gênero. Tradução Liane Schneider. Estudos Feministas, [s. l.], v. 10, n. 1, p. 171-188, 2002. Disponível em: https://bit.ly/2Py6Z7i. Acesso em: 8 mar. 2021.

DAMASCO, Mariana Santos; MAIO, Marcos Chor; MONTEIRO, Simone. Feminismo negro: raça, identidade e saúde reprodutiva no Brasil (1975-1993). Rev. Estud. Fem., Florianópolis, v. 20, n. 1, p. 133-151, jan./abr. 2012. Disponível em: https://bit.ly/3xCeGKX. Acesso em: 8 mar. 2021.

DAVIS, Angela. Mulheres, raça e classe. São Paulo: Boitempo, 2016.

DINIZ, Débora; ALMEIDA, Marcos de. Bioética e Aborto. In: COSTA, Sergio Ibiapina Ferreira; OSELKA, Gabriel; GARRAFA, Volnei (coord.). Iniciação à bioética. Brasília: Conselho Federal de Medicina, 1998. p. 125-137. Disponível em: https://bit.ly/3xvD1li. Acesso em: 8 mar. 2021.

DINIZ, Debora; MEDEIROS, Marcelo; MADEIRO, Alberto. Pesquisa Nacional de Aborto 2016. Ciênc. saúde coletiva, Rio de Janeiro, v. 22, n. 2, p. 653-660, 2017. Disponível em: https://bit.ly/32QxojJ. Acesso em: 8 mar. 2021.

DONATH, Orna. Mães arrependidas: uma outra visão da maternidade. Rio de Janeiro: Civilização Brasileira, 2017.

EMMERICK, Rulian. Corpo e Poder: Um Olhar Sobre o Aborto à Luz dos Direitos Humanos e da Democracia. 2007. 199 p. Dissertação (Mestrado em Direito) - Centro de Ciências Sociais, Pontifícia Universidade Católica do Rio de Janeiro, Rio de Janeiro, 2007. Disponível em: https://bit.ly/3aKZpgN. Acesso em: 8 mar. 2021.

FLAUZINA, Ana Luiza Pinheiro. Corpo negro caído no chão: o sistema penal e o projeto genocida do Estado brasileiro. Rio de Janeiro: Contraponto, 2008. 
FOUCAULT, Michel. História da sexualidade. V. 1. A vontade de saber. Rio de Janeiro: Graal, 1999.

FOUCAULT, Michel. Vigiar e Punir. Nascimento da prisão. Tradução Raquel Ramalhete. Petrópolis: Vozes, 1987.

GONZALEZ, Lélia. Racismo e sexismo na cultura brasileira. In: RIOS, Flavia; LIMA, Márcia (org.). Por um feminismo afro-latino-americano. Ensaios, intervenções e diálogos. Rio de Janeiro: Zahar, 2020. p. 75-93.

HARAWAY, Donna. Ecce Homo, Ain’t (Ar’n't) I a Woman, and Inappropriate/d Others: The Human in a Post-Humanist Landscape. In: BUTLER, Judith; SCOTT, Joan W. (ed.). Feminists Theorize the Political. New York: Routledge, 1992. p. 86-100.

HARDING, Sandra. A instabilidade das categorias analíticas na teoria feminista. Tradução Vera Pereira. Estudos Feministas, [s. l.], v. 2, n. 1, p. 7-31, 1993. Disponível em: https://bit.ly/3eBjyaj. Acesso em: 8 mar. 2021.

HOPP, Cecilia M. Política criminal sobre el aborto: la sexualidad femenina en debate. Revista Derecho Penal, [s. l.], ano I, n. 2, p. 135-159, 2012. Disponível em: https://bit.ly/3xoOdQV. Acesso em: 8 mar. 2021.

KREUZ, Leticia Regina Camargo. Crime e pecado: o aborto sob os véus da religiosidade, da moralidade, da juridicidade e do feminismo. 2016. 235 p. Dissertação (Mestrado em Direito) Programa de Pós-graduação em Direito, Setor de Ciências Jurídicas, Universidade Federal do Paraná, Curitiba, 2016.

LIMA, Nathália Diórgenes Ferreira; CORDEIRO, Rosineide de Lourdes Meira. Aborto, racismo e violência: reflexões a partir do feminismo negro. Em Pauta, Rio de Janeiro, v. 18, n. 46, p. 101117, $2^{\circ}$ sem. 2020.

MACHADO, Marta R. de A.; MACIEL, Débora A. The Battle Over Abortion Rights in Brazil's State Arenas, 1995-2006. Health and Human Rights Journal, [s. l.], v. 19, n. 1, p. 119-131, June 2017.

NICOLÁS, Gemma. Debates en epistemologia feminista: del empirismo y el standpoint a las críticas postmodernas sobre el sujeto y el punto de vista. In: NICOLÁS, Gemma et al. (comp.). Género y dominación: críticas feministas al derecho y al poder. Barcelona: Anthropos, 2009. p. 25-62.

OSIS, Maria José D. et al. Dificuldades para obter informações da população de mulheres sobre aborto ilegal. Rev. Saúde Pública, [s. l.], v. 30, n. 5, p. 444-451, 1996. Disponível em: https://bit.ly/3dUgvuz. Acesso em: 8 mar. 2021.

PITCH, Tamar. Justicia penal y libertad femenina. In: NICOLÁS, Gemma et al. (comp.). Género y dominación: críticas feministas al derecho y al poder. Barcelona: Anthropos, 2009. p. 117-126.

POOVEY, Mary. The Abortion Question and the Death of Man. In: BUTLER, Judith; SCOTT, Joan W. (ed.). Feminists Theorize the Political. New York: Routledge, 1992. p. 239-256. 
QUEIROZ, Antônio Augusto de. O Congresso mais conservador dos últimos quarenta anos. Le Monde Diplomatique Brasil, [s. l.], ed. 136, 5 nov. 2018. Disponível em: https://bit.ly/2R78U2M. Acesso em: 8 mar. 2021.

QUIJANO, Aníbal. Colonialidade do poder, eurocentrismo e América Latina. In: LANDER, Edgardo (org.) A colonialidade do saber: eurocentrismo e ciências sociais. Perspectivas latinoamericanas. Buenos Aires: CLACSO, 2005. p. 117-142.

RIO DE JANEIRO. Defensoria Pública do Estado do Rio de Janeiro. Diretoria de estudos e pesquisas de acesso à justiça [Relatório - levantamento de dados a partir da consulta aos processos de aborto em trâmite no estado do Rio de Janeiro, com o objetivo de traçar o perfil das mulheres que são criminalizadas por esse tipo de conduta]. 1 nov. 2017. 30 p. Disponível em: https://bit.ly/3eCjqHr. Acesso em: 8 mar. 2021.

SAFFIOTI, Heleieth I. B. O poder do macho. São Paulo: Moderna, 1987.

SANTOS, Rayani Mariano dos. O debate parlamentar sobre aborto no Brasil: atores, posições e argumentos. 2015. 222 p. Dissertação (Mestrado em Ciência Política) - Programa de PósGraduação em Ciência Política, Instituto de Ciência Política, Universidade de Brasília, Brasília, 2015. Disponível em: https://bit.ly/2Uw5KYz. Acesso em: 8 mar. 2021.

SCOTT, Joan. Gênero: uma categoria útil de análise histórica. Educação \& Realidade, Porto Alegre, v. 20, n. 2, p. 71-99. jul./dez. 1995. Disponível em: https://bit.ly/3gKAtdc. Acesso em: 8 mar. 2021.

VILA-NOVA, Carolina. Ministra Damares Alves agiu para impedir aborto em criança de 10 anos. Folha de S.Paulo, São Paulo, 20 set. 2020. Disponível em: https://bit.ly/3vrUzwL. Acesso em: 8 mar. 2021.

ZAFFARONI, Eugenio Raúl et al. Direito Penal Brasileiro. V. I. Rio de Janeiro: Revan, 2003. 